\title{
Vocational Education, Training and Employment for Young People in England and Wales: journeying through a gendered landscape
}

\section{Lorna Unwin}

This paper explores the gendered landscape of vocational education and training in England and Wales. At the start of the 21st century, young people in England and Wales can still choose between leaving school at the age of 16 or remaining in fulltime education. Having made that key decision, however, they then face a further bewildering set of choices, for each route then sub-divides into a number of pathways. For some young explorers, the journey will be straightforward, whereas many will face obstacles and setbacks along the way due to the effects of their gender, ethnicity or social class. The paper examines the extent to which young people can exert agency when determining their futures given the continuing power of structural determinants. To this end, the paper maps the routes which young people can take after compulsory schooling and analyses the relationship between post-compulsory provision and the labour market. The paper concludes that we need to properly understand this landscape in order to help young people in their decision making.

\section{Introduction}

At the start of the 21st century, young people in England and Wales can still choose between leaving school at the age of 16 or remaining in full-time education. Having made that key decision, however, they then face a further bewildering set of choices, for each route then sub-divides into a number of pathways. For some young explorers, the journey will be straightforward, whereas many will face obstacles and setbacks along the way due to the effects of their gender, ethnicity or social class. Socio-economic and cultural factors still play a huge role in determining young people's life chances, though as Evans (1998), drawing on Beck (1992), has argued, we should remember that all young people are increasingly facing unprecedented levels of risk:

Traditional socialising agencies such as the extended and nuclear family, the church and the school no longer act as agencies of social reproduction; they no longer channel individuals into predetermined niches and levels of society. Rather, it is argued, an infinite range of courses of action has opened up for people. This results in increased levels of risk for all, the "risk society". (Evans, 1998, p. 22) 
In this paper, I will explore the extent to which gender still influences the way in which young people are likely to experience vocational education, training and employment in England and Wales. (For a discussion of recent developments in post-compulsory education and training in Scotland, see Howieson, C. et al., 1997; Scottish Office, 1994). Devolved government to the new Welsh Assembly is having an impact on education and training policymaking in Wales (see Jenkins et al., 1997) which may see a greater convergence of the academic and vocational routes. Currently, however, there are many more similarities between England and Wales than there are differences.

It is worth noting at the start of this paper that figures for 1998/99 show that, in full-time education, girls are continuing to perform better than boys at aged 16 and 18. At 16, 53.4\% of girls obtained five or more GCSEs at Grades A-C compared to $42.8 \%$ of boys, while at $18,71.9 \%$ of girls achieved two or more A levels compared to $65.4 \%$ of boys. (DfEE, 1999a) As this paper will try to show, however, this performance does not mean that girls, necessarily, capitalise on those early gains.

\section{Making the first journey}

The map which all young people must read before making their decisions provides the following possible routes and pathways:

\section{Route One}

1. Continue in full-time education either in school, sixth form college or further education (FE) college.

\section{Route One Pathways}

a) Study for A Level qualifications (academic subjects)

b) Study for General National Vocational Qualifications (GNVQs) in a range of topics including: Leisure and Tourism; Health and Social Care; Engineering; Art and Design; Business; Construction and the Built Environment; Hospitality and Catering; Manufacturing; Media-Communication and Production; Performing Arts and Entertainment; Retail Services; and Science.

c) Study for a traditional vocational qualification.

d) Study for a mixture of GNVQs and A Levels.

\section{Route Two}

Leave full-time education.

\section{Route Two Pathways}

1. Seek employment (full-time or part-time work)

2. Enter a government-sponsored training scheme - National Traineeship or Modern Apprenticeship. Modern Apprenticeship is route is open to 16 to 25 
year olds making it an option for young people who have remained in full-time education until 18 or even to university graduates.

3. Embark on a mix of part-time further education and part-time work.

4. Choose not to participate in any further education, training or mode of employment (this may be because of illness, pregnancy, or through a lack of desire to pursue the options on offer).

To say that young people «choose» between these routes and pathways is, of course, highly problematic. In many cases, the decision-making may be done by someone other than the young person. For example, in relation to deciding whether or not to remain in full-time education, a young person's choice may be affected as follows: her parents might decide which A levels she should pursue; a school might refuse to let her progress into its post-compulsory provision thus forcing an application to a local college; and a school may persuade her to take a GNVQ course rather than A levels. Ball et al. (1999, p. 42) remind us that:

«In almost all families, parents provide a general framework of aspirations and hopes for their children, a space within which choices are made and validated.»

Where a young person has decided to try and find employment, it is the employer who will decide whether, for example, a young person should be offered training under the Modern Apprenticeship initiative (see Unwin and Wellington, 1995) or simple receive the barest of training in the workplace.

The «structural and situational influences», as defined by Banks, et. al. (1992), which impact on young people's decision-making have to be considered alongside the ability of young people to exercise agency in their decision-making in order to exert some control over their lives. Given the complicated map of post-compulsory provision in England and Wales, it is not surprising that young people often find it difficult to balance the demands of structure and agency.

\section{The academic-vocational divide}

An academic/vocational divide still shapes the structure and curricula content of both compulsory and post-compulsory education in England and Wales which is rooted in Platonic notions of dividing people according to their mental and manual capabilities (see Pring, 1995; Tomlinson, 1997). We see this today in the workplace through the occupational divisions between professionals, technicians and operatives. The 1944 Education Act introduced the concept of grammar (academic), technical (advanced vocational) and secondary modern (preparation for work) schools. Although an attempt was made to sweep this aside through the introduction of comprehensive schools in the early 1970s, the division is still very visible when one looks at the post-16 qualifications available in schools and colleges today: A levels (for the academically able); GNVQs ( at Advanced and Intermediate levels for those in the middle); and GNVQs at Foundation level for 
the «less able». These divisions can, of course, be overcome. Hence, young people with GNVQs are entering higher education whilst some young people with A levels have chosen to join the Modern Apprenticeship where they will work towards competence-based National Vocational Qualifications (NVQs) related to their occupational area.

Since the introduction of NVQs (SVQs in Scotland) in 1986, the United Kingdom (UK) has had a national qualifications framework which purports to give "parity of esteem" to the academic and vocational qualifications which it embraces. An Intermediate GNVQ is, therefore, said to be equivalent to $4 \mathrm{GC}$ SEs (grades A-C) and to an NVQ at Level 2, whilst an Advanced GNVQ is said to be equivalent to $2 \mathrm{~A}$ levels and to an NVQ at Level 3. The UK interpretation of what constitutes the academic as opposed to the vocational has, however, always favoured the academic, which is said to have depth and rigour and involve considerable mental ability, over the vocational where «doing» is seen to be more important than «knowing». This contrasts to the approach taken by the UK's European neighbours, notably France and Germany, who offer young people the opportunity to follow an academic or vocational route which are regarded as being equally demanding (see Green and Steedman, 1993).

A desire to promote "parity of esteem» can be said to arise out of notions of equity and fairness and parity is a useful motivating device for schools and colleges who want to encourage young people to take their courses. In reality, however, the concept of "parity" is dangerous if it gives young people a false picture of how qualifications and courses are valued in the world outside the classroom. To say this does not imply a belief that the Platonic categorisations were correct, but young people need to know that their peers with academic qualifications still have greater access to further and higher education, to higher paid jobs, and to positions of status within society.

For young women, who still face discrimination in the labour market, a realistic awareness of the ways in which the qualifications structure operates outside educational institutions is vital. For example, Felstead, et. al. (1995) have shown that women do not have equal access to vocational qualifications in the workplace unless they are in a female-dominated occupational sector such as cleri$\mathrm{cal} /$ secretarial, personal services (e.g. hairdressing, retailing) or healthcare (e.g. nursing, childcare). Bynner's (1999, p. 82) analysis of the British birth-cohort data bases shows that:

except at the highest occupational levels, women get less work-based training than do men, and women with children get the least training of all.

He continues:

Women without children and with the most human and social capital, as represented by the jobs they are in, lag only a little behind men with respect to the work-based training received, and in certain occupations, these women may surpass them. Those women with very little human and social capital, and especially those with children, lag substantially behind men at every occupational level, but 
especially at the lowest occupational levels, which $70 \%$ of women with poor basic skills enter (ibid).

Given that the UK has the highest rate of teenage single mothers in Europe, it is of great concern that these young women will face substantial difficulties in attempting to gain and improve their employability skills.

\section{Gender and work}

Vocational qualifications, which reflect the organisation and character of the world of work, are, necessarily, more gendered than their academic counterparts. Given the increase in the numbers of young people remaining in full-time education after 16, many of whom are taking vocational qualifications (largely GNVQs), we could be witnessing the stereotypical divisions of the world of work being further entrenched in schools and colleges.

Young people's images of jobs, careers and the concept of «work» are formed very early in life. Francis (1996), in her study of the future occupational aspirations of 7-11 year olds in a London primary school, found that «many girls chose powerful, high-status jobs» but:

... a binary gender dichotomy appears to remain between the type or attributes of jobs chosen by girls and boys, with more girls opting for artistic or caring occupations, and boys choosing more scientific or sporting jobs. Moreover, few children chose jobs which are traditionally performed by the opposite sex. (Francis, 1996, p. 57)

In their study of male and female trainees on the then government-sponsored Youth Training (YT) scheme in Devon and Cornwall, Hodkinson, et. al. (1996) found some evidence to support Gaskell's (1992) claim that young women relate their choice of job to their future roles as wives and mothers though, for some women, such thoughts only surfaced once they had moved closer to taking on domestic responsibilities, such as moving in with a boyfriend. Hodkinson, et.al's study suggests that young women do exert much more agency in their decisionmaking than Gaskell's work maintains. However, their study also points out that when young women choose to enter a traditionally male occupational sector, they have to fight against sexist attitudes from fellow workers, fellow students and employers.

Breaking down the initial barrier is particularly hard for girls and boys if they are not supported by the adults in their lives. In her study of women graduates who entered non-traditional jobs in the technical professions (science and engineering), Devine (1994, p. 72) found that although their parents had been supportive, these women had faced hostility from non-specialist teachers and careers advisors, "regarding their choice of degree and subsequent occupation on the grounds that it was an inappropriate job for a woman». Jenny Ozga's collection of personal accounts of women in educational management shows the difficul- 
ties they face resulting in the decision by many women to reject management because «the price is too high». Sadly, such decisions mean that the very institutions (schools, colleges, universities) which could offer support and inspiration to female students have limited numbers of female role models. (Ozga, 1993, p. 9)

Much of the empirical research which has examined young people's decisionmaking processes related to careers, training and qualifications has been qualitative, and often ethnographic in its methodological approach. As Bates and Riseborough (1993) point out this means that the young people who have been studied are located across a large number of settings and contexts. The research can, therefore, present us with very rich accounts of individual young people, or present us with a profile of young people in a specific area, but it would be dangerous to over-generalise those findings for all young people. In her study of 1618 year old girls on a YT course in «caring» and on a BTEC National Diploma course in fashion design, Bates (1993a and 1993b) analyses the social, domestic and economic restrictions operating at local level against which these girls had to make their decisions. Detailed awareness of such restrictions and their impact on young people's attitudes and concepts should, ideally, be developed by all those responsible for guiding and advising young people about their post-16 choices.

In their study of post-16 destination patterns in Derbyshire, Fergusson and Unwin (1996) found that even within one English county, there were distinctly different cultural and socio-economic influences affecting young people's choices. For example, in one small town, the nature of local industry meant there was still a steady supply of jobs for 16 year old boys regardless of their academic achievement. Boys from the local comprehensive school were, therefore, attuned to the idea of leaving school well before the time came for them to make that decision.

The government-supported training route (National Traineeships and Modern Apprenticeship) for school leavers in the UK, unsurprisingly, also reflects the gendered world of work. Much has been written about the problems of youth training schemes in the UK in terms of their general lack of quality and overall failure to provide an adequate vocational education to young people (see, inter alia, Unwin, 1997). Many of these schemes do, of course, offer young people real jobs with reputable employers and the chance to achieve vocational qualifications. The statistics show, however, that, on the whole, they have not helped young people break out of stereotypical job patterns.

Modern Apprenticeship (MA), launched in 1994, and aiming to provide a higher status work-based route, follows this trend by dividing males and females into traditional sectors. By the end of September 1999, there were some 135,700 apprentices on the MA in England, of whom just under 50\% are female. (DfEE, 1999b) Female apprentices are mainly located in traditional female sectors such as Childcare (97\%), Health and Social Care (89\%), Hairdressing (92\%) and Business Administration (79\%). (ibid) Male apprentices dominate in sectors such as Engineering Manufacture (97\%), Construction (99\%), and Information 
Technology (73\%). (ibid) The only sectors with approaching equal numbers of males and females are Hotel and Catering (46\% female) and Retailing (58\% female).

The MA has raised the status of the work-based route through its insistence that young people work towards a minimum of NVQ Level 3 (in contrast to Level 2 on previous youth training schemes), and that they are directly employed rather than being on the books of a training provider. But the MA has, as yet, done little to advance the cause of both men and women who want to enter nontraditional areas of work. By segregating female apprentices into what Payne (1991) has called the "narrow range of occupations traditionally regarded as 'woman's work'", it could be condemning them to the less well paid jobs which offer less scope for advancement. It is particularly disappointing that Information Technology has attracted far less young women than men given the importance of this sector to both the global and national economies and the growing opportunities it provides for jobs.

Whilst YT and the MA can help us gain a picture of the gendered landscape of the youth labour market, we have to remember that significant numbers of young people leave school to enter jobs which are unconnected to the state-supported training schemes, and many will have been working part-time for at least the last two years of their period in full-time education. Again, local conditions play a key role here in determining the extent to which young people can gain experience of the world of work and the extent to which that experience will be determined by gender. One of the main employers of part-time youth labour is the retail industry whose supermarkets and shops rely heavily on school and college students (males and females) in the evenings and at weekends when the other main source of labour for retailers, married women, want to take time off. Unwin's (1995) research on young people in the North West of England, found that both girls and boys were working an average of 12 hours per week in supermarkets for which they received relatively good rates of pay. In their study of over 2,000 school, college and university full-time students, Lucas and Lammont (1998) found that part-time work was an accepted part of their lives (see also Huddleston and Unwin, 1997).

Whilst equality of opportunity appears to be in operation for students who choose to work part-time, the industry takes a different view when it comes to its relatively small numbers of full-time staff. Ashton, et. al. (1990) show that the armies of part-time married women and students are managed by a highly trained core of largely male employees.

Whilst part-time work does provide young people with important financial support and with useful employment-related key skills, it also inducts them into a complex set of structures and behavioural attitudes, many of which have gendered origins (see Skeggs, 1988). Discussions of the relationship between parttime work and full-time education tend to concentrate on the argument that students should be able to make use of their employment experiences in their 
studies, particularly if they are on vocational courses. There is, of course, some merit in suggesting that because part-time work forms a considerable part of many young people's lives, it is counterproductive for schools and colleges not to draw on this experience. Perhaps of greater importance, however, is that teachers and careers guidance professionals should create opportunities for young people to discuss and analyse their work experience in order to develop a more sophisticated understanding of how the labour market is constructed and the implications of its structures for career and further eduation decision-making. Part of that discussion might focus on the limitations of part-time work which, though it may appear attractive to a 16 year old (flexible hours, relatively good pay), offers little in the way of security or occupational advancement. For young women, such a discussion might help them look beyond their domestic horizons which could be dangerously entrenched through part-time work which brings them into contact with older women who are fitting their job around home and family.

The youth labour market is also characterised by its role in the informal economy where young people are often willing to work long hours and move from job to job, and are less concerned than more mature adults about health and safety regulations and other legislative matters whih govern jobs in the formal economy. Fergusson and Unwin's study of Derbyshire (op.cit), found that boys in inner-city Derby were leaving school, often part way through Year 11, to work on local building sites on a daily contract basis. This is an under-researched field both in terms of the academic literature and the from the point of view of the agencies who provide advice and guidance to young people. Griffin (1993), for example, reminds us that the sex industry is a significant source of informal employment for both girls and boys. A realistic picture of their local labour market in all its manifestations should be available to all young people and needs to be understood by the adults who provide them with advice and guidance.

\section{Changing the Landscape}

There is no shortage of research focusing on young people's decision-making much of which suggests that structure rather than agency is the more dominant imperative. Young women are thought to have limited horizons unless they are products of single-sex grammar schools where they are taught to believe they can achieve just as much if not more than men (see, for example, Deem, 1984). Careers officers will recount frustrating conversations with legions of girls who want to beome nursery nurses or hairdressers, yet admit that there are jobs available in these sectors. University admissions' tutors bemoan the lack of female applicants to science and engineering courses but do not stop to question how well they support women on such courses or the extent to which the courses themselves might project a macho culture. Young men and boys have now become a cause for concern because they are falling behind their female peers in the aca- 
demic race. One explanation for this is that in some areas of England and Wales, they have little hope in gaining meaningful employment and so cannot see any point in working hard at school.

The gendered landscape of post-compulsory education and training presents a considerable barrier to young people who want to exert some agency in their lives and, at the same time, creates a major problem for those charged with advising young people about post-16 choices. Young people often make pragmatic decisions based on their knowledge of local and, sometimes, national conditions in eduation and employment. They may know more than the adults who try to advise them. Yet, those pragmatic decisions may only be appropriate in the short-term and may lock the young person into a straightjacket they find hard to escape. The challenge, therefore, is to find a balance between respecting young people's images and knowledge of the different options presented to them, and attempting to enourage young people to explore less safe or unusual alternatives. Young people do, of course, break down barriers and challenge stereotypical attitudes and patterns of working. We need to know more about how they do this and what they need by way of support to enable them to continue to succeed.

\section{References}

Ashton, D., Maguire, M. \& Spilsbury, M. (1990). Restructuring the Labour Market. London: MacMillan.

Ball, S.J., Macrae, S. \& Maguire, M. (1999). Young lives at risk in the «futures» market: some policy concerns from ongoing research. In Coffield, F. (Ed.). Speaking Truth to Power. Bristol: The Policy Press.

Banks, M., et. al. (1992). Careers and Identities. Milton Keynes: Open University Press.

Bates, I. \& Riseborough, G. (1993) (Ed.). Youth and Inequality. Buckingham: Open University Press.

Bates, I. (1993a). A Job Which is "Right for Me"? In Bates, I. \& Riseborough, G. op. cit.

Bates, I. (1993b). «When I have my own studio...» The Making and Shaping of «Designer Careers» In Bates, I. \& Riseborough, G. op. cit.

Beck, U. (1992). Risk Society. London: Sage Publications.

Bynner, J. (1999). New Routes to Employment: Integration and Exclusion. In Heinz, W. (ed.) From Education to Work: Cross-National Perspectives. Cambridge: Cambridge University Press.

DfEE (1999a) GCSE/GNVQ and GCE A/AS/Advanced GNVQ Results for Young People in England 1998/99, Statistical First Release 35/1999. London, Department for Education and Employment.

DfEE (1999b) TEC/CCTE Delivered Government Supported Training: work-based training for young people and work-based learning for adults, England and Wales, Statistical First Release 39/1999. London: Department for Education and Employment.

Deem, R. (1984). Co-education Reconsidered. Milton Keyne: Open University Press.

Devine, F. (1994). Gender segregation and labour supply: on «choosing» gender a-typical jobs. British Journal of Education and Work, 6, (3), 61-72.

Evans, K. (1998). Shaping Futures, Learning for Competence and Citizenship. Aldershot: Ashgate. Felstead, A., Goodwin, J. \& Green, F. (1995). Measuring Up to the National Training Targets: Women's Attainment of Vocational Qualifiations. Centre for Labour Market Studies: University of Leicester. 
Fergusson, R. \& Unwin, L. (1996). Making Better Sense of Post-16 Destinations: a case study of an English shire county. Research Papers in Education, 11, (1).

Francis, B (1996). Doctor/Nurse, Teacher/Caretaker: Children's Gendered Choice of Adult Occupation in Interviews and Role Plays. British Journal of Education and Work, 9, (3), 47-58.

Gaskell, J. (1992). Gender Matters from School to Work. Buckingham: Open University Press.

Green, A. \& Steedman, H. (1993). Educational Provision, Educational Attainment and the Needs of Industry: A Review of the Research for Germany, France, Japan, the USA and Britain, Report No.5. London: National Institute for Economic and Social Research.

Griffin, C. (1993). Representations of Youth. Cambridge: Polity Press.

Hodkinson, P., Sparkes, A.C. \& Hodkinson, H. (1996). Triumphs and Tears: Young People, Markets and the Transition from School to Work. London: David Fulton.

Howieson, C., Raffe, D., Spours, K. \& Young, M. (1997). Unifying academic and vocational learning: the state of the debate in England and Scotland, Unified Learning Project Working Paper 1. Journal of Education and Work, 10, (1), 5-35.

Huddleston, P. \& Unwin, L. (1997). Skills, stakeholders and star-gazing: the relationship between education, training and the economy. London: Further Education Development Agency mimeo.

Jenkins, C., David, J., Osmond, J. \& Pierce, J. (1997). The Welsh Baccalaureat: Educating Wales in the next century. Cardiff: Institute of Welsh Affairs.

Lucas, R. \& Lammont, N. (1998) Combining work and study: an empirical study of full-time students in school, college and university. Journal of Education and Work, 11, (1), 41-56.

Ozga, J. (1993) (ed.), Introduction: In a Different Mode, Women in Educational Management, Buckingham: Open University Press.

Payne, J. (1991). Women, Training and the Skills Shortage, London: Policy Studies Institute.

Pring, R. (1995). Closing the Gap: Liberal Education and Vocational Preparation. London: Hodder and Stoughton. 14-19 Qualifications, Frameworks and Systems, London: Kogan Page.

Scottish Office (1994). Higher Still: Opportunity for all, Edinburgh: HMSO.

Skeggs, B. (1988). Gender Reproduction and Further Education: domestic apprenticeships. British Journal of Sociology of Education, 9, (2), 131-150.

Tomlinson, S. (1997). Education 14-19 Critical Perspectives, London: The Athlone Press.

Unwin, L. (1995). Staying the Course: Students Reasons for Non-completion of Full-time Education courses in South and East Cheshire, Middlewich, South and East Cheshire. EducationBusiness Partnership.

Unwin, L. \& Wellington, J. (1995). Reconstructing the work-based route: lessons from the Modern Apprenticeship. Journal of Vocational Education and Training, 47, (4), 337 - 352.

Unwin, L. (1997). Reforming the work-based route: problems and potential for change. In Hodgson, A. and Spours, K. (eds.), Dearing and Beyond, 14-19 Qualifications, Frameworks and Systems. London: Kogan Page, 75 - 87. 


\section{Berufsbildung und Beschäftigung von Jugendlichen in Eng- land und Wales: Eine Reise durch eine geschlechtsspezifisch geprägte Landschaft}

\section{Zusammenfassung}

Der Beitrag untersucht die geschlechtsspezifisch geprägte Landschaft der Berufsbildung in England und Wales. Am Anfang des 21. Jahrhunderts können Jugendliche hier immer noch zwischen dem Verlassen der Schule mit 16 Jahren und dem Verbleiben in einer Vollzeitschule wählen. Nach dieser Schlüsselentscheidung stehen sie jedoch einem verwirrenden Set von Wahlmöglichkeiten gegenüber, wobei jeder Ausbildungsgang wiederum unterteilt ist. Für einige Jugendliche geht der Weg geradeaus, während viele mit Hindernissen und Rückschlägen konfrontiert sind. Der Text fragt nach den Entscheidungsmöglichkeiten, die Jugendlichen aufgrund ihres Geschlechts sowie ihrer ethnischen und sozialen Zugehörigkeit und angesichts der faktischen Macht der strukturellen Determinanten zur Verfügung stehen. Zu diesem Zweck zeichnet der Beitrag die Ausbildungswege, welche Jugendlichen nach der obligatorischen Schulzeit offen stehen, nach und analysiert die Zusammenhänge zwischen nachobligatorischer Ausbildung und Arbeitsmarkt. Der Beitrag kommt zum Schluss, dass man diese Landschaft sehr gut verstehen muss, um Jugendliche bei ihren Entscheiden unterstützen zu können.

\section{Formation professionnelle, préparation et entrée dans le monde du travail des jeunes en Angleterre et au Pays de Galles: voyage à travers un pasage marqué par des spécificités liées au genre.}

\section{Résumé}

Cet article explore l'univers de la formation professionnelle et de l'apprentissage en Angleterre et dans le pays de Galles du point de vue du genre. A l'aube du $21 \mathrm{e}$ siècle, les jeunes Gallois et Anglais peuvent toujours décider, à la fin de la scolarité obligatoire, s'ils désirent quitter l'école à 16 ans ou suivre un cursus de formation à plein temps. Ayant fait ce choix crucial, il leur reste toutefois une palette déroutante d'options, car chacune des deux possibilités débouchent sur de nombreuses voies. Pour certains jeunes «explorateurs», le voyage sera simple, alors que beaucoup d'autres rencontreront des obstacles et essuieront des échecs en chemin, revers dus à leur genre, leur origine ethnique ou leur classe sociale. L'article analyse dans quelle mesure les jeunes gens peuvent exercer un rôle d'agent dans la détermination de leur avenir vu la force constante des déterminants structurels. A cette fin, l'article dresse une carte des filières que les jeunes gens peuvent suivre après la scolarité obligatoire et analyse l'adéquation entre les apports des cursus de formation post-obligatoires et le marché du travail. L'ar- 
ticle conclut qu'il est nécessaire de comprendre ce paysage afin d'aider les jeunes dans leurs prises de décision.

\title{
Formazione professionale e occupazione giovanile in Inghilterra e nel Galles: un viaggio attraverso un paesaggio caratterizzato dalla questione dell'appartenenza sessuale
}

\author{
Riassunto
}

L'articolo esplora la situazione della formazione professionale in Inghilterra e nel Galles sotto il profilo degli effetti che può avere l'appartenenza all'uno o all'altro sesso sulla formazione. All'inizio del XXImo secolo i giovani inglesi possono sempre ancora scegliere di lasciare la scuola a 16 anni o di restare in un percorso formativo a tempo pieno. Dopo aver preso questa decisione, si trovano confrontati con un nuovo quadro di scelte non semplici che comportano a loro volta una serie di percorsi differenziati. Fra questi «giovani esploratori», taluni troveranno una strada veloce e proiettata in avanti, altri invece dovranno affrontare ostacoli e contraccolpi a causa del loro sesso, della loro origine etnica e sociale. L'articolo esamina fino a che punto i giovani possono incidere sul loro futuro se si considera la continua pressione esercitata dai fattori strutturali. Di seguito si tracciano i percorsi che i giovani possono seguire dopo la scuola dell'obbligo e analizza la relazione esistente tra i servizi disponibili dopo la scuola e il mondo del lavoro. Infine si conclude sottolineando l'importanza di una conoscenza appropriata di questa realtà per poter aiutare i giovani a prendere decisioni appropriate. 